\title{
Strategy of Russian Coal Mining Enterprises' Excavator Park Technical State Correction
}

\author{
Michael Drygin ${ }^{1, *}$, Nicholas Kurychkin ${ }^{1}$ and Alexander Bakanov ${ }^{1}$ \\ ${ }^{1}$ T. F. Gorbachev Kuzbass State Technical University, 28 Vesennya str. Kemerovo 650000, Russia
}

\begin{abstract}
Coal extraction in Russian Federation increases by $3 \ldots 4 \%$. This tendency will remain in the nearest $10 \ldots 15$ years. Opencast mining makes $(70 \ldots 72) \%$ from the total extraction in the country. Though analysis shows that investments in coal mining within the last 25 years were insignificant. In these conditions the priority area for coal production cost reduction and increasing productivity of opencast coal mines is optimization of the main technological equipment (excavator park) maintenance system. The article shows that current system of scheduled preventive repair is not efficient and requires to be changed to the system of repair works due to actual state of the equipment.
\end{abstract}

\section{Introduction}

Fuel and energy complex is a vitally important part of the world economy. Consumption rates for energy products increase year to year with the growth of the world gross product [1]. Currently basic energy sources are natural gas, oil, coal, pyroshales and uranium. Oil and gas play the main role but their reserves gradually decrease and will be completely exhausted by the 2050 s $[2,3]$. At the same time coal deposits are enough for about 200 years even at the maximal extraction rates.

Regardless of the world economy downfall coal is still one of the crucial Russia's energy resources stabilizing the situation in the power industry [4, 5]. In the end of 2015, there were 245 coal mining and processing enterprises in the country; 70 of them are mines, 119 opencast mines, and 56 processing plants. Together there were $373.4 \mathrm{mln}$ tons of coal extracted (Fig. 1), of them 269 mln tons were extracted by opencast method.

Russian Federation is the sixth in the world in coal extraction and the fourth in coal consumption. Kuznetsk coal bearing basin (Kuzbass), is one of the largest in Russia and in the world (Fig. 2) [6].

Thus in 2015, export that was yearly increasing by $5-15 \%$ remained practically the same as in $2014-151.4$ mln tons. Within the last five year steady positive growth of coal export turnover can be observed, and Kuzbass made Russia the third in coal export after Australia and Indonesia [7, 8]. Coal from Kuzbass is exported to 85 countries of the world.

\footnotetext{
* Corresponding author: mike.drygin@gmail.com
} 


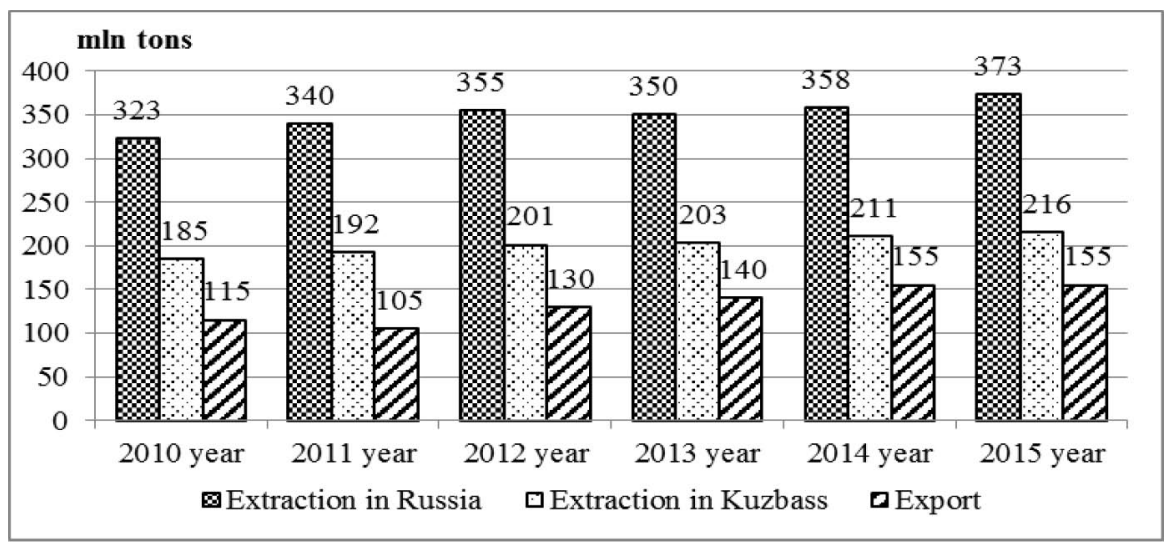

Fig. 1. Coal Extraction Dynamics for Russia and Kuzbass

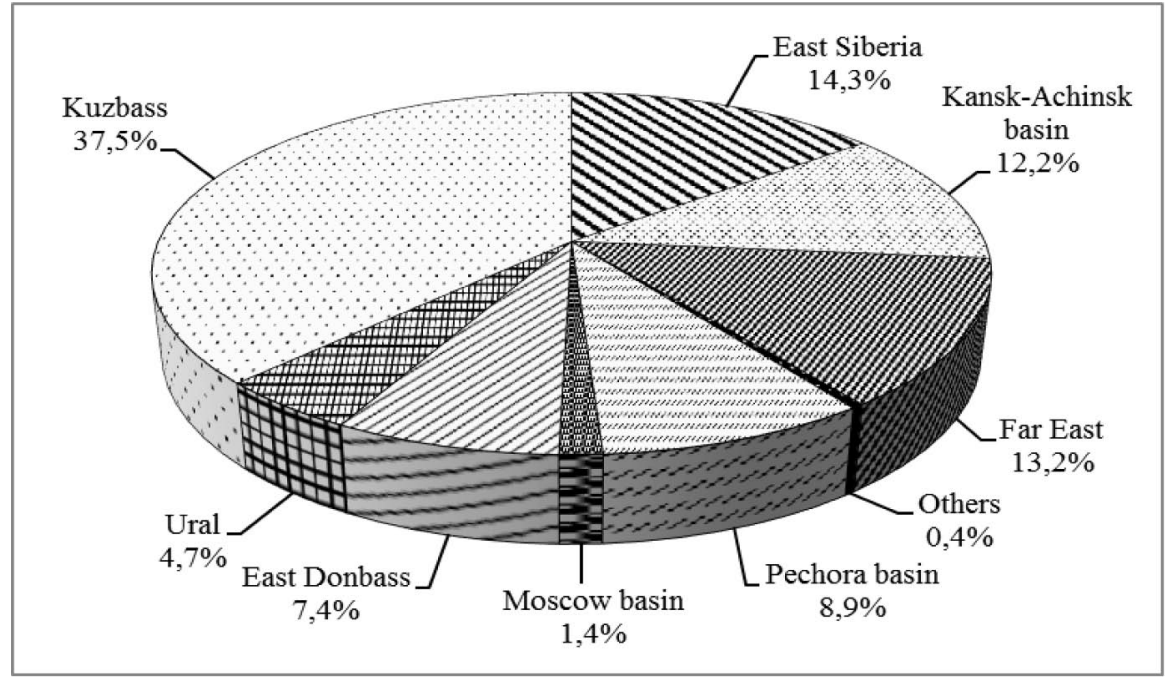

Fig. 2. Extracted Coal Percentage by Regions

The tendency for the increase of coal extraction within the country will remain in the nearest $10-15$ years (Table 1) $[9,10]$. Though, regarding the crisis in the economy $[11,12]$, by 2030, coal extraction in Russia will hardly correspond to the forecast 550-650 thousand tons. Extraction of 450-500 thousand tons looks the most real, and around $40 \%$ of this coal will be mined in Kuzbass, and $70 \%$ of it mined by opencast method $[13,14]$.

Table 1. Coal Extraction Factors in Russia

\begin{tabular}{|l|c|c|c|c|c|}
\hline \multirow{2}{*}{ Factors } & \multicolumn{2}{c|}{ In fact } & \multicolumn{3}{c|}{ Forecast by years } \\
\cline { 2 - 6 } & $\mathbf{2 0 1 0}$ & $\mathbf{2 0 1 5}$ & $\mathbf{2 0 2 0}$ & $\mathbf{2 0 2 5}$ & $\mathbf{2 0 3 0}$ \\
\hline Coal extraction in Russia, mln tons & $360-375$ & $425-445$ & $470-485$ & $515-580$ & $565-650$ \\
\hline Kuznetsk basin, mln tons & $180-190$ & $215-250$ & $230-250$ & $255-300$ & $275-330$ \\
\hline $\begin{array}{l}\text { Kemerovo region share in the total } \\
\text { extraction in Russia, \% }\end{array}$ & 50 & $50-51$ & $49-51$ & $50-52$ & $49-51$ \\
\hline
\end{tabular}




\section{Results and Discussion}

Opencast method has some obvious advantages in comparison with underground one: higher efficiency, low producing cost and safer mining work. That is the reason why $70 \%$ of the coal mined in Russia is extracted by opencast method, and this factor is steadily growing together with total extraction volume. Thus in 2015, it grew by $2 \%$ compared with 2014 and by $41 \%$ compared with 2000 .

Nonetheless investments in the coal industry within the last 25 years were not considerable. Even in the most stable 2010 they remained at the level of $5 \%$ of the revenue from coal sales (Fig. 3), though during the post-soviet period practically up to 2000 investments in the coal mining enterprises were minute. At the moment these investments target building of modern technological complexes for coal extraction, processing and enrichment.

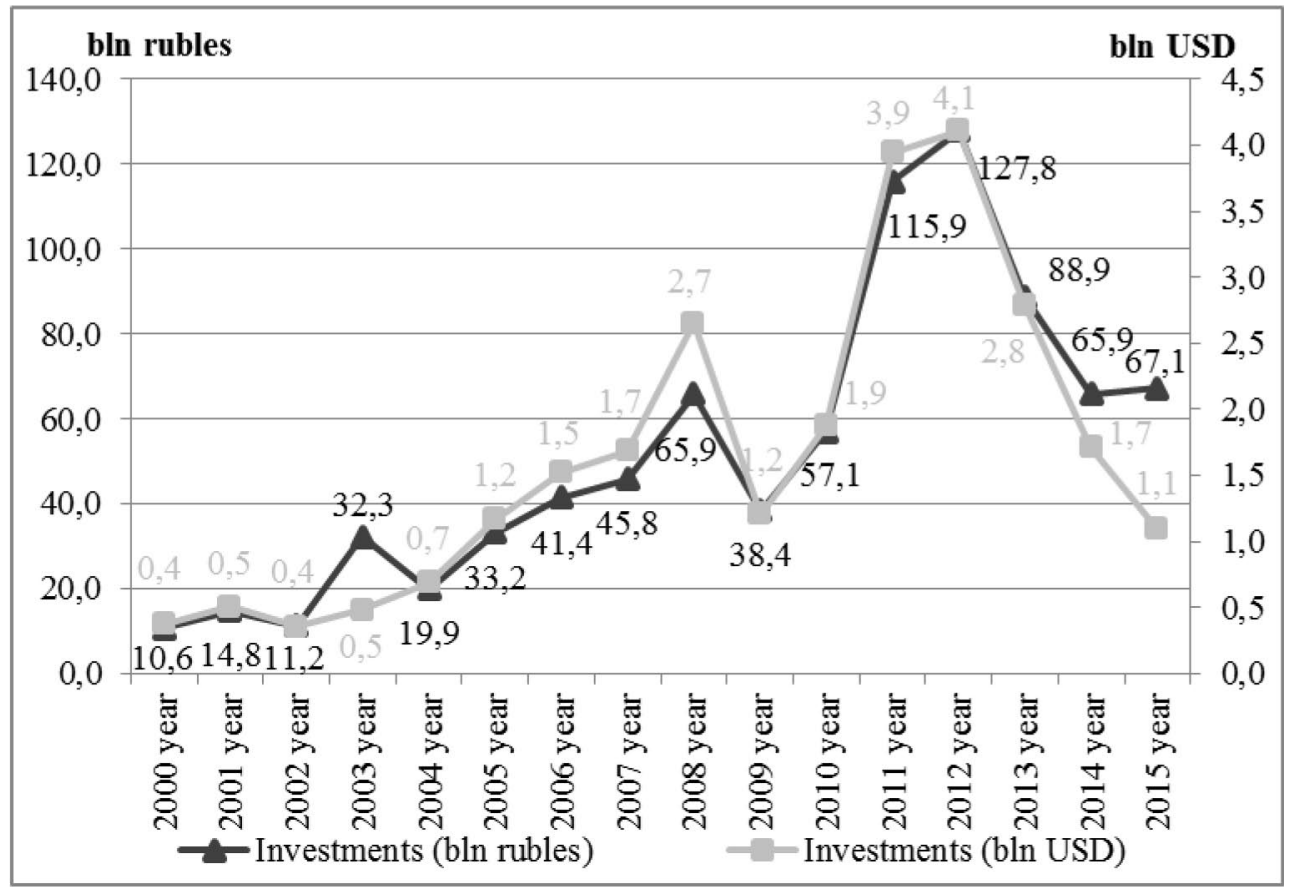

Fig. 3. Investments in Coal Mining Enterprises in Russia

Therefore, while average labour productivity has grown twice within the last decade and reached 200 tons per person monthly (though it is lower than average numbers for the world), the only logical solution for this situation is reducing of coal production cost. Cost reduction is possible only due to growth of the main technological equipment productivity, mainly excavators.

The renewal of the current technological equipment park at opencast coal mines is much slower than it is required. Though Russian and particularly Kuzbass coal mining enterprises are monitored by the supervisory authorities of RosTekhNadzor (Federal Service for Environmental, Technological, and Nuclear Supervision), and $70 \%$ of the equipment is practically every year undergoes the procedure of industrial safety expert review, diagnostic procedures included in the required set of works necessary for equipment service life extension are minimal, formal and fragmentary, and are not enough for its fault-free service.

At mining enterprises basically outmoded equipment and technical devices were replaced but the excavator park was hardly renewed. Due to corrective actions (performed on paper as well) technical devices with expired standard service life are used. 
As a rule, meanings that characterize the number of basic production facilities run despite of expired standard service life period vary widely from region to region depending on operating organizations and companies. However, as a part of general tendency, it is possible to highlight single-time renewal of excavator park segment replacing excavators manufactured in the Soviet Union with the equivalent ones manufactured in Russia. This renewal is basically performed by putting into operation shovel dredges manufactured in Russia, USA and China with bucket capacity more than $18-20 \mathrm{~m}^{3}$.

Analysis of Russian mining enterprises' excavator park shows that the main part of the park includes crawler mounted mining shovels with bucket capacity of 8-15 $\mathrm{m}^{3}$ manufactured by OMZ IZ-KARTEX (Fig. 4).

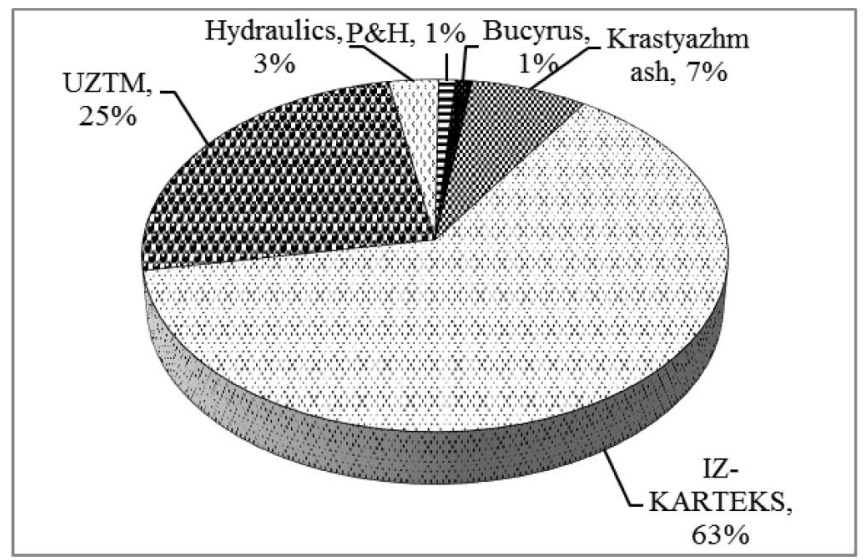

Fig. 4. Structure of Excavator Park of Mining Enterprises

The further analysis is carried out on the basis of the largest coal mining company of Kuzbass as it is the closest to the modern tendencies of Russian coal mining enterprises' excavator park renewal. This is OAO Kuzbassrazrezugol - the second Russian company with the largest coal extraction volume.

According to data from 16 January 2016, opencast mines of OAO UK Kuzbassrazrezugol use 264 technological excavators, of them 169 mining power shovels, 56 walking draglines and 39 hydraulic excavators. 157 excavators of the total number outlasted standard service life period. Within 12 months of 2015, 1 excavator was put into operation and 8 excavators were written-off. Most of the technological excavators are used in Kuzbass. The main current tendencies are removal from operation of the excavators manufactured in the Soviet Union which exceeded their safe usage date, and putting into operation the excavators with bucket capacity from $18 \mathrm{~m} 3$ to $40 \mathrm{~m}^{3}$ and more. However notwithstanding putting the new equipment into operation the average age of the operating equipment is growing and in 2015, it reached 16 years (Fig. 5).

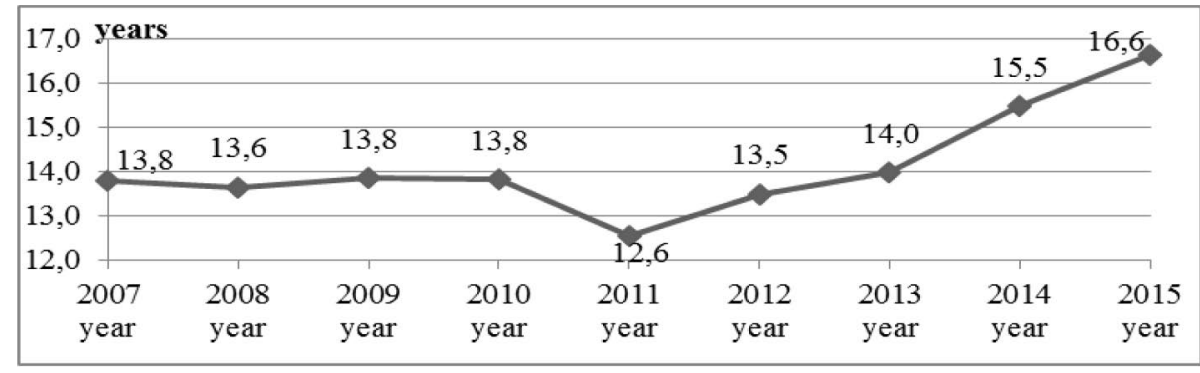

Fig. 5. Average Service Life of Excavators 
The tendencies for changing the extent of park wear by service life and the performed score of work practically do not change (Fig. 6). Only in 2011, a lot of new equipment was delivered, and this delayed only for a year reaching the $100 \%$ level of excavator park wear extent.

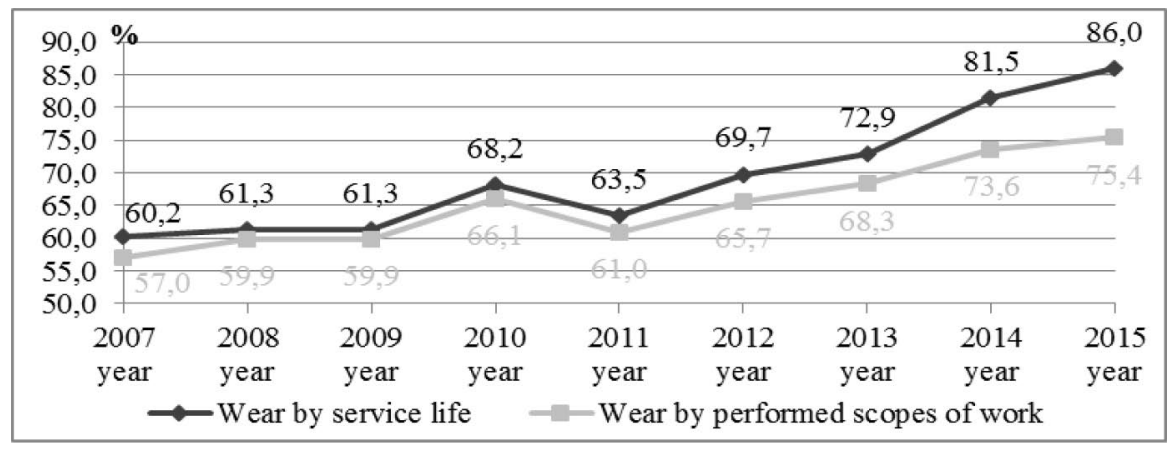

Fig. 6. Dynamic of UK Kuzbassrazrezugol Excavator Park Wear by Service Life and Performed Scope of Work

Thus for 1 January, 2016, the extent of wear for the park of open-pit excavators made $75.4 \%$ by the performed scope of work and $86 \%$ by the service life.

Average extent of excavator park wear at UK Kuzbassrazrezugol currently exceeded $80 \%$. A great deal of excavators are in operation more than 15-25 years, and service live of more than $45 \%$ excavators are in excess of industry norms.

Analyzing the diagram on Fig. 6, it can be said that wear of the excavator park by performed scope of work until 2011, practically mirrors the wear by service life and then begins to deviate significantly, primarily highlights the decrease of total productivity of the park, ad it means that an excavator works out the time but does not work out the scope of work. The further forecasts are discouraging. Without any changes the excavator park of UK Kuzbassrazrezugol will reach the $100 \%$ level of wear extent by 2018 , and total wear of the park by performed scope of work.

Purchase of new equipment is necessary for park renewal. For instance, yearly purchase with the volume equivalent to 2010 , would help to reduce the extent of park wear to $67 \%$ and $57 \%$ of wear by the service life and by the performed scope of work respectively.

Previously described situation causes the necessity of renewal of Kuzbass mining enterprises' excavator park and search for new organizational and technical solutions of currently used equipment operation. At the moment the following main tendencies can be mentioned. The first is putting into operation of new excavators with large bucket capacity which is required by growing demands for productivity and loading of mining trucks with bearing capacity excising 220 tons.

The second tendency is removal from operation of low-powered hydraulic excavators and excavators manufactured in the Soviet Union usually up to $8 \mathrm{~m}^{3}$, which had exceeded their safe usage date. Low-powered hydraulic excavators of foreign origin up to $8 \mathrm{~m}^{3}$ which showed high mobility are usually put in use in contour coal mining [15-18].

Generally, considering the tendencies of the early 2000s based on total replacement of the park of excavators manufactured in Russia with foreign hydraulic ones it can be said that this strategy proved inefficient. The advantages of the foreign equipment during its use during the first year were come to nothing after 4-5 years of use. Thus introduction of foreign equipment except current expenditure demanded significant operating costs, and tough interrepair maintenance requirements caused the necessity of total routine maintenance system revision. Thus in the majority of cases such equipment is under post-warranty mainte- 
nance and requires continuous presence of the technical support engineer, and absence of any technical documents and structural complexity of basic mechanisms required plant repair, and, as a rule, this lead to per-unit repair.

One of an excavator's efficient work factors is using of the calendar working time fund, exactly, increase of working time at downtime reduction. It is necessary to understand that total absence of pauses and downtime is impossible, there is a need for proper organization of work for the personnel, including organizational workers, so that the equipment was provided with «routine maintenance», and in case of repair everything necessary for it would be available (Fig. 7).

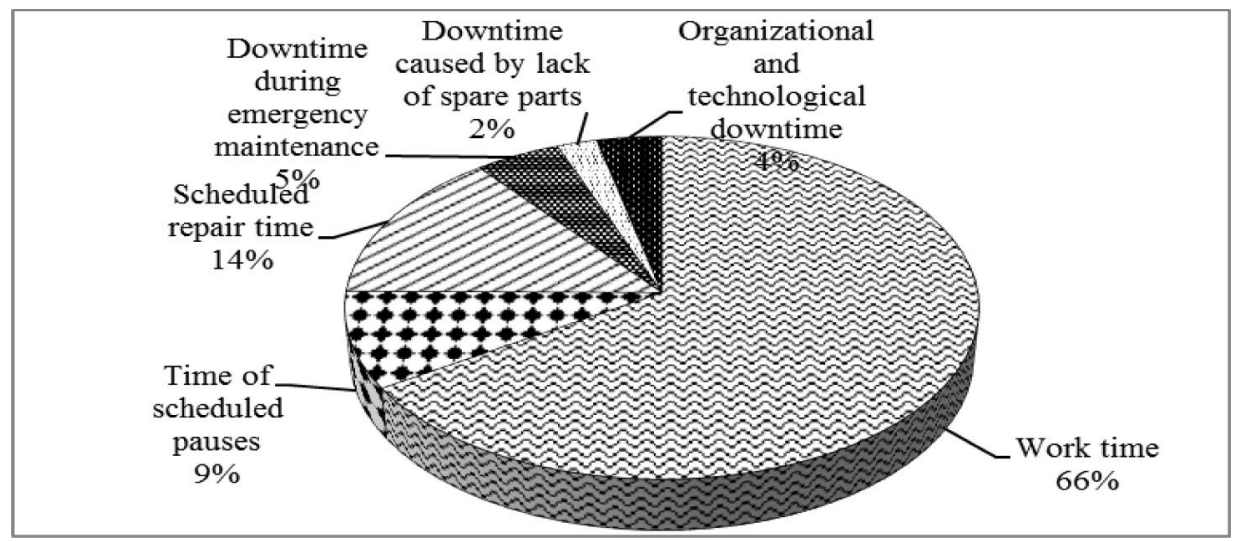

Fig. 7. Using the Calendar Working Time Fund of an Excavator at UK Kuzbassrazrezugol for 2015.

Periodic equipment maintenance presupposes various scope and set time of repair. Incidence rate work and scope of repair are specified by the scheduled preventive repair (SPR) system of the enterprise [19]. In accordance with this system overall annual downtime under scheduled repair make from 50 to 90 days per year and determined by the following factors: extent of equipment wear; qualification of operating and maintenance stuff; quality of delivered spare parts; climatic, mining and geological conditions of the repair works.

Except the SPR system there is system of repair works caused by actual state of equipment [20]. Analysis shows that the system of equipment actual state reacts to the same number of faults that the SPR system but removes troubles much faster (Fig. 8).

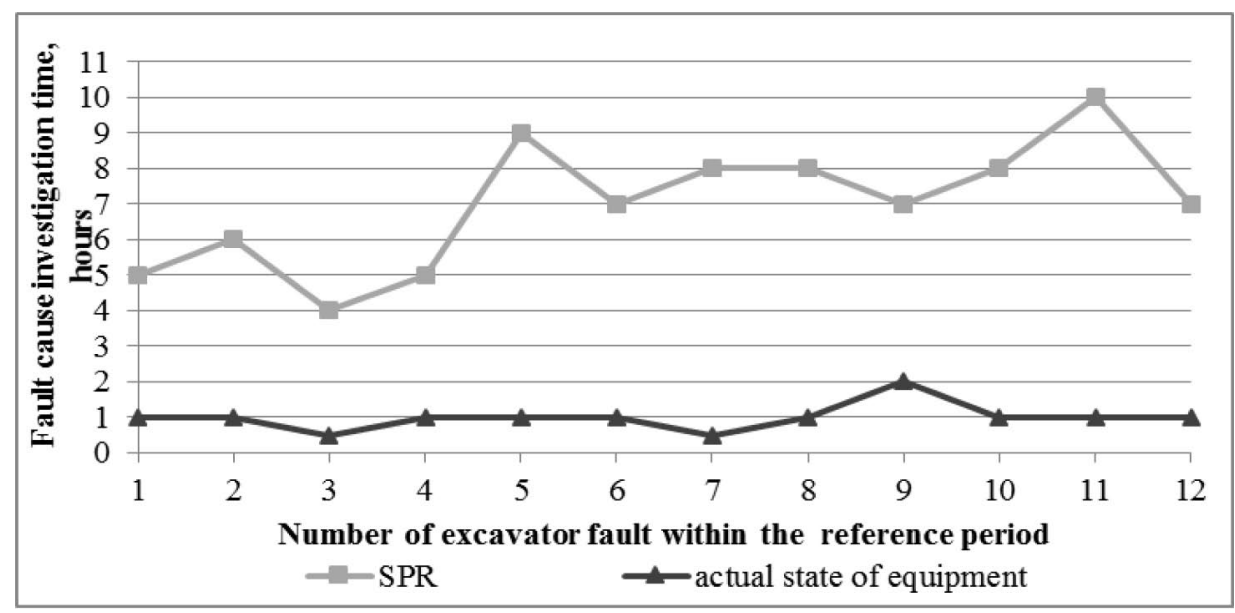

Fig. 8. Comparison of equipment actual state and SPR(organizational and diagnostic) 


\section{Conclusions}

Analysis of the above information allows us to draw the following conclusions.

1. Development of coal mining in Russian Federation comes with extraction volume growth.

2. The tendency for renewal of the excavator park at opencast coal mines is insignificant, and excavators put into operation do not play any major role in coal extraction growth.

3. Annual capacity of excavators drops due to downtime increase.

4. Current system of scheduled preventive repair of excavators is not efficient and requires to be changed to the system of repair works due to actual state of the equipment.

\section{References}

1. J. Conti, The International Energy Outlook 2016 (2016)

2. M. J. Kaiser, Y. Yu, Oil \& Gas Fin. J. 9, 1 (2012)

3. M. J. Kaiser, Y. Yu, Oil \& Gas Fin. J. 9, 2 (2012)

4. H. Arden, A. Tverdov, Resource and Reserve Valuation Practices in CIS Countries (2014)

5. Statistic review of Emerging Markets Information Service "Coal Mining Sector Russia"

https://www.emis.com/sites/default/files/Russia/Coal/Mining/Sector/Report.pdf

6. S A Zhironkin, A A Khoreshok, M A Tyulenev, G A Barysheva, M C Hellmer IOP Conference Series: Materials Science and Engineering, 142, 1 (2016)

7. B. Heath, Report of Coal Industry Advisory Board International Coal Policy Developments in 2015 (2015)

8. International Energy Agency's technical paper on "Key Coal Trends" (2016) https://www.iea.org/publications/freepublications/publication/KeyCoalTrends.pdf

9. L. Grossman, R. Gebhard, M. Haala, H.-J. Seger, M. Smiarowski, R. Bursch, Coal Age 121, 52 (2016)

10. Project Survey 2017: Industry Indicators Improve. E\&MJ, 2017

11. V. Vorotnikov, Coal Age, 121, 48 (2016)

12. T. Saywell, The N. Min., 101, 7 (2015)

13. A. Harris, S. Hall, K. Brown, O. Munnion, Ditch Coal: the global mining impacts of the UK's addiction to coal (2016)

14. V.A. Kovalev, A.A. Khoreshok, O.I. Litvin, The 8th Russian-Chinese Symposium. Coal in the 21st Century: Mining, Processing and Safety, 287 (2016)

15. M.A. Tyulenev, T.N. Gvozdkova, S.A. Zhironkin, E.A. Garina, Geotech. Geol. Eng., 35:1, 203 (2017)

16. M.A. Tyulenev, S.A. Zhironkin, E.A. Garina, Int. J. of Mining and Mineral Engineering, 7:4, 363 (2016)

17. A.B. Efremenkov, A.A. Khoreshok, S.A. Zhironkin, A.V. Myaskov, IOP Conf. Ser.: Earth Environ. Sci. 50, 012009 (2017)

18. M. Tyulenev, E. Garina, A. Khoreshok, O. Litvin, Y. Litvin, E. Maliukhina, IOP Conf. Ser.: Earth Environ. Sci., 50, 012035 (2017)

19. Fleet management. Mining Magazine 44 (2013)

20. A. Morshedlou, H. Dehghani, S. H. Hoseinie, JME, 5, 113 (2014) 